TUNAS Jurnal Pendidikan Guru Sekolah Dasar, Desember 2016, Volume 2 Nomor 1 (16-20) http://jurnal.umpalangkaraya.ac.id/ejurnal/tunas

\title{
UPAYA MENINGKATKAN HASIL BELAJAR MATEMATIKA DENGAN MENERAPKAN MODEL PEMBELAJARAN KOOPERATIF TIPE THINK PAIR SHARE (TPS) PADA PESERTA DIDIK KELAS III SDN-6 SELAT HILIR KUALA KAPUAS TAHUN PELAJARAN 2014/2015
}

\author{
Oleh \\ Nurul Ramadhaniy, Nurul Hikmah Kartini
}

\begin{abstract}
ABSTRAK
Penelitian ini bertujuan untuk (1) mendeskripsikan aktivitas peserta didik dalam kegiatan belajar mengajar dengan menerapkan model pembelajaran kooperatif tipe Think Pair Share (TPS) (2) mengetahui peningkatan hasil belajar matematika pada peserta didik kelas III SDN 6 Selat Hilir setelah menerapkan model pembelajaran kooperatif tipe Think Pair Share (TPS).

Metode yang digunakan oleh peneliti adalah menggunakan rancangan penelitian tindakan kelas (PTK) yang berusaha memecahkan atau menjawab permasalahan yang dihadapi pada situasi sekarang. Dengan jumlah subyek penelitian 16 orang peserta didik. Teknik analisis data didasarkan pada hasil siklus dari tiap proses pembelajaran.

Hasil penelitian menunjukan bahwa: (1) aktivitas peserta didik dengan diterapkannya model pembelajaran kooperatif tipe Think Pair Share (TPS) lebih aktif dan mengalami peningkatan di setiap siklus. Pada siklus I skor rata - rata yang diperoleh peserta didik 2,6 dengan kriteria cukup baik, siklus II skor rata - rata yang diperoleh peserta didik 3,8 dengan kriteria baik, (2) ada peningkatan hasil belajar Matematika melalui penerapan model pembelajaran kooperatif tipe Think Pair Share (TPS) yang menunjukan dari hasil belajar pada siklus I diperoleh rata-rata 64,68 dan ketuntasan secara klasikalnya yaitu 62,5\% dan siklus II diperoleh rata-rata 79,68 dan ketuntasan secara klasikal yaitu 93,75\%.
\end{abstract}

(C) Universitas Muhammadiyah Palangkaraya

\section{Kata Kunci: Hasil Belajar, Think Pair Share (TPS), Matematika.}

\section{PENDAHULUAN}

Matematika mempunyai peranan penting terhadap kemajuan teknologi dan ilmu pengetahuan. Mata pelajaran matematika berfungsi sebagai mata pelajaran yang mengembangkan kemampuan berkomunikasi dengan menggunakan bilangan - bilangan dan simbol - simbol serta ketajaman penalaran yang membantu memperjelas dan memecahkan permasalahan dalam kehidupan sehari - hari.

Sumarmo dkk (Susanto, 2013:

191) mengemukakan bahwa "hasil belajar matematika peserta didik sekolah dasar belum memuaskan, juga adanya kesulitan belajar yang dihadapi peserta didik dan kesulitan yang dihadapi guru dalam mengajarkan matematika". Hasil penelitian Soedadji (Susanto, 2013: 191) juga 
mengemukakan bahwa " Daya serap rata - rata peserta didik sekolah dasar untuk mata pelajaran matematika hanya sebesar 42\%".

Berdasarkan pada pendapat para ahli di atas, hasil belajar matematika belum memuaskan karena peserta didik kurang tertarik dan merasa bosan, Selain itu, proses pembelajaran yang dilakukan masih berpusat pada guru (teacher centered), model pembelajaran yang kurang bervariasi sehingga peserta didik kurang bersemangat dalam mengikuti pelajaran. Interaksi antara guru dengan peserta didik dan antar-peserta didik sangat sedikit .Hal tersebut berdampak pada hasil belajar matematika peserta didik menjadi kurang memuaskan.

$$
\text { Hasil observasi peneliti }
$$

terhadap peserta didik kelas III di SDN6 Selat Hilir, diketahui bahwa hasil belajar matematika peserta didik masih banyak yang belum memenuhi Kriteria Ketuntasan Minimal (KKM) 6,00 yang telah ditetapkan oleh sekolah. Hal ini terlihat dari hasil ulangan 16 peserta didik yaitu sebanyak $75 \%$ atau 12 peserta didik mendapatkan nilai dibawah Kriteria Ketuntasan Minimal (KKM) dengan rata - rata 4,33. Sedangkan sisanya $25 \%$ atau 4 peserta didik mendapatkan nilai di atas rata rata yaitu 6,75 .

Dari permasalahan tersebut, perlu perbaikan dalam pembelajaran matematika, dan peranan guru sangat diperlukan. Pembelajaran matematika diharapkan tidak hanya dengan mentransfer pengetahuan saja tetapi juga membantu peserta didik untuk membentuk pengetahuan mereka sendiri serta memberdayakannya untuk memecahkan masalah - masalah yang dihadapi. Upaya itu antara lain dengan menggunakan model pembelajaran yang variatif.

Sugiyanto (Ningsih, 2011: 3) mengemukakan bahwa "Pembelajaran yang kreatif dan inovatif salah satunya tercermin dalam model pembelajaran kooperatif. Model pembelajaran kooperatif sendiri terdiri dari berbagai macam metode, diantaranya STAD, Jigsaw, GI, dan Struktural". Model pembelajaran kooperatif tipe struktural yaitu metode yang menekankan pada struktur yang mempengaruhi pola pola interaksi peserta didik. Teknik dalam model pembelajaran kooperatif tipe struktural ini adalah Think Pair Share. Dalam bukunya Cooperative Learning, Anita Lie (Ningsih, 2011: 4) menyebutkan bahwa "Think Pair Share adalah salah satu tipe model pembelajaran kooperatif yang cocok diterapkan untuk semua mata pelajaran dan semua tingkat usia anak".

"Think Pair Share atau berpikir berpasangan berbagi adalah merupakan jenis pembelajaran kooperatif yang dirancang untuk mempengaruhi pola interaksi peserta didik" (Trianto,2009: 81). Think Pair Share (TPS) ini dikembangkan oleh Frank Lyman dan koleganya di Universitas Maryland. Arends (Trianto, 2009: 81) menyatakan bahwa:

Think Pair Share (TPS) merupakan suatu cara yang efektif untuk membuat variasi suasana pola diskusi kelas. Dengan asumsi bahwa semua resitasi atau diskusi membutuhkan 
pengaturan untuk mengendalikan kelas secara keseluruhan, dan prosedur yang digunakan Think Pair Share (TPS) dapat memberi siswa lebih banyak waktu berpikir, untuk merespons dan saling membantu.

Adapun Langkah - langkah pelaksanaan Think Pair Share (TPS) menurut (Trianto, 2009: 81 - 82):

1) Thinking (Berpikir)

Guru mengajukan suatu pertanyaan atau masalah yang dikaitkan dengan pelajaran, dan meminta peserta didik menggunakan waktu beberapa menit untuk berpikir sendiri jawaban atau masalah. Peserta didik membutuhkan penjelasan bahwa berbicara atau mengerjakan bukan bagian berpikir.

2) Pairing (Berpasangan)

Selanjutnya guru meminta peserta didik untuk berpasangan dan mendiskusikan apa yang telah mereka peroleh. Interaksi selama waktu yang disediakan dapat menyatukan jawaban jika suatu pertanyaan yang diajukan atau menyatukan gagasan apabila suatu masalah khusus yang diidentifikasikan. Secara normal guru memberi waktu tidak lebih dari 4 atau 5 menit untuk berpasangan.

3) Sharing (Berbagi)

Pada langkah akhir, guru meminta pasangan - pasangan untuk berbagi dengan pasangan lain. Hal ini efektif untuk berkeliling ruangan dari pasangan ke pasangan dan melanjutkan sampai sekitar sebagian pasangan mendapatkan kesempatan untuk melaporkan.

\section{METODE PENELITIAN}

Penelitian ini menggunakan Penelitian Tindakan Kelas (PTK). Penelitian Tindakan Kelas (PTK) adalah proses pengkajian masalah pembelajaran di dalam kelas melalui refleksi diri dan upaya untuk memecahkannya dengan cara melakukan berbagai tindakan yang terencana dalam situasi nyata serta menganilis setiap pengaruh dari tindakan tersebut.

Kehadiran dan peran peneliti dalam penelitian ini adalah sebagai orang yang menyadari adanya permasalahan. Peneliti berperan sebagai pengamat, perencana, pelaksana, pengumpul data, penganalisis data, dan perancang tindakan. Selama penelitian berlangsung, peneliti saling bekerja sama dengan guru kelas.

Dalam penelitian ini, yang menjadi subjek penelitian adalah seluruh peserta didik kelas III SDN 6 Selat Hilir yang berjumlah 16 anak. Terdiri dari 9 peserta didik lali - laki dan 7 peserta didik perempuan. Objek penelitian ini adalah keseluruhan proses dan hasil pembelajaran matematika dengan menggunakan model pembelajaran kooperatif tipe Think Pair Share (TPS) dalam rangka meningkatkan hasil belajar peserta didik kelas III SDN 6 Selat Hilir.

Pengumpulan data yang digunakan dalam penelitian ini yaitu menggunkan observasi (pengamatan) mengenai aktivitas peserta didik dalam pembelajaran dan tes yang digunakan 
untuk mengukur kemampuan peserta didik (tes hasil belajar).

Data yang dikumpulkan dari setiap kegiatan yang akan dilaksanakan dalam siklus PTK dianalisis secara deskriptif dengan menggunakan teknik presentase untuk melihat kecenderungan yang terjadi dalam pembelajaran. data yang diperoleh melalui instrument sebelumnya diolah lebih dulu menjadi dua jenis yaitu data kualitatif dan kuantitatif.

Data kualitaif digunakan untuk memberi keterangan tentang proses pembelajaran. Sedangkan data kuantitatif digunakan untuk mengetahui jumlah peningkatan hasil belajar peserta didik setelah proses pembelajaran melalui model pembelajaran kooperatif tipe Think Pair Share (TPS) berlangsung.

\section{HASIL DAN PEMBAHASAN}

\section{Hasil Pengamatan Aktivitas Guru dan Peserta Didik}

Aktivitas guru dan peserta didik melalui pembelajaran menggunakan model pembelajaran kooperatif tipe Think Pair Share (TPS) pada materi bangun datar di kelas III SDN 6 Selat Hilir Kuala Kapuas menunjukkan perkembangan yang baik. Nilai rata rata aktivitas guru pada siklus I adalah 2,9 dan rata - rata aktivitas peserta didik diperoleh nilai 2,6. Sedangkan pada siklus II, nilai rata - rata aktivitas guru meningkat menjadi 3,5 dan rata - rata aktivitas peserta didik juga mengalami peningkatan yaitu 3,8 .

\section{Hasil Belajar Peserta Didik}

Hasil belajar yang diperoleh berdasarkan hasil tes pada peserta didik kelas III SDN 6 Selat Hilir Kuala

Kapuas yang menggunakan model pembelajaran kooperatif tipe Think Pair Share (TPS) dapat terlihat dari grafik di bawah ini:

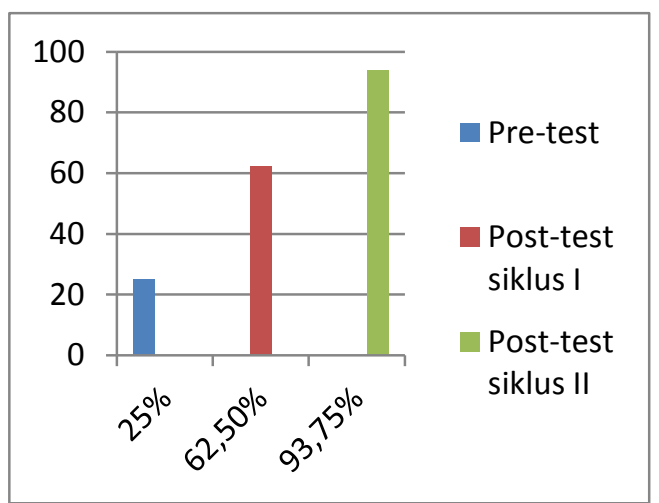

Gambar 1

Peningkatan Hasil Belajar Matematika Secara Klasikal

Berdasarkan grafik di atas, dapat dilihat bahwa pada tes awal atau pretest nilai rata-rata peserta didik hanya memperoleh nilai rata-rata 51,25. Nilai ini masih jauh dari kriteria ketuntasan minimal (KKM) yang ditentukan yaitu 60. Hasil ketuntasan belajar secara klasikal juga hanya memperoleh nilai sebesar 25\%, sedangkan kriteria ketuntasan klasikalnya minimal $85 \%$. Kemudian pada siklus I nilai rata-rata peserta didik mengalami peningkatan sebesar 64,68 dan ketuntasan belajar secara klasikalnya $62,5 \%$. Namun ini belum cukup dikarenakan kriteria ketuntasan klasikal minimal $85 \%$ peserta didik yang tuntas dalam belajar. Pada siklus II nilai rata-rata peserta didik mengalami peningkatan cukup bagus dengan perolehan nilai rata-rata 79,68 dengan kriteria ketuntasan secara klasikal mencapai 93,75\%. Peneliti 
menganggap pada siklus II ini sudah berhasil karena telah mencapai nilai ketuntasan secara klasikal, dapat terlihat dari perkembangan pre-test hingga posttest siklus II nilai peserta didik tersebut tetap mengalami peningkatan.

\section{SIMPULAN}

Berdasarkan hasil penelitian yang telah dibahas maka dapat disimpulkan beberapa hal yaitu:

1. Aktivitas belajar peserta didik pada pembelajaran Matematika setelah menerapkan model pembelajaran kooperatif tipe Think Pair Share (TPS) pada kelas III SDN 6 Selat Hilir Tahun Pelajaran 2014/2015 lebih aktif. Pada siklus I, skor aktivitas peserta didik 2,6 dengan kriteria cukup baik, siklus II skor rata - rata 3,8 dengan kriteria baik.

2. Ada peningkatan hasil belajar peserta didik pada mata pelajaran Matematika setelah menerapkan model pembelajaran kooperatif tipe Think Pair Share (TPS) pada kelas III SDN 6 Selat Hilir Tahun Pelajaran 2014/2015. Nilai rata rata pre-test yaitu 51,25 , siklus I 64,68 dan siklus II 79,68 dengan ketuntasan klasikal 93,75\%.

\section{DAFTAR PUSTAKA}

Ningsih, A.Y. (2011). Penggunaan

Media Kelereng Dalam Model

Pembelajaran Kooperatif (Think

Pair Share) Untuk Meningkatkan

Kemampuan Berhitung Perkalian

Siswa. Universitas Sebelas Maret

Surakarta
Susanto, A. (2013). Teori Belajar \& Pembelajaran di Sekolah Dasar. Jakarta: Kencana Prenada Media Group.

Trianto. (2009). Mendesain Model Pembelajaran Inovatif-Progresif. Jakarta: Kencana Prenada Media Group 